\title{
KAITAN KOMPENSASI TERHADAP KEPUASAN KERJA KARYAWAN DENGAN KEPEMIMPINAN SEBAGAI MODERATING VARIABLE (Studi Pada Kantor UPT. Bina Marga Jember)
}

\section{CORELLATION OF COMPENSATION ON EMPLOYEE SATISFACTION WITH LEADERSHIP AS MODERATING VARIABLE (Study Held in UPT Bina Marga Jember)}

\author{
Ira Puspitadewi S. \\ Prodi Manajemen Fakultas Ekonomi Universitas Muhammadiyah Jember \\ E-mail: irapuspita@unmuhjember.ac.id
}

\begin{abstract}
ABSTRAK
Penelitian mengenai kontribusi kompensasi terhadap kepuasan kerja karyawan dengan kepemimpinan sebagai moderating variable. Merupakan studi pada UPT Bina Marga Jember. Tujuan yang ingin dicapai adalah untuk mengetahui pengaruh kontribusi kompensasi, interaksi antara kontribusi kompensasi dan kepemimpinan terhadap kepuasan kerja karyawan. Populasi pada penelitian ini berjumlah 31 orang karyawan. Pengumpulan data dilakukan dengan mendistribusikan kuesioner kepada responden. Analisis data dalam penelitian ini menggunakan aplikasi SPSS versi 16. Teknik pengujian data menggunakan Uji instrumen data yang meliputi Uji Validitas, Uji Reliabilitas dan Uji Normalitas Data. Untuk menguji dan membuktikan hipotesis penelitian, menggunakan metode; Uji Asumsi Klasik, Analisis Deskriptif Statistik, Regresi Linear Sederhana, Moderated Regression Analysis (MRA) dan terakhir, dilakukan pengujian hipotesis yang meliputi Uji t dan Koefisien Determinasi. Dari analisis data yang dilakukan, diperoleh hasil bahwa kontribusi kompensasi berpengaruh terhadap kepuasan kerja karyawan dengan arah positif dan ada interaksi antara kontribusi kompensasi dan kepemimpinan terhadap kepuasan kerja karyawan. Hal ini berarti bahwa kepemimpinan merupakan variabel pemoderasi antara kontribusi kompensasi terhadap kepuasan kerja karyawan.
\end{abstract}

Kata Kunci: Kontribusi Kompensasi, Kepuasan Kerja, Kepemimpinan.

\begin{abstract}
The research of contribution compensation to employee satisfaction with leadership as a moderating variable. is a study at UPT Bina Marga Jember. This research was aimed to finding out the effect of compensation contribution, the interaction between compensation contributions and leadership on employee job satisfaction. The population in this research amounted to 31 employees. Data was collected by distributing questionnaires to the respondents. Data analysis in this research using SPSS application version 16. Mechanical testing of data using the instrument test data covering Validity Test, Reliability Test and Normality Test Data. To test and prove the hypotheses of the research, using the method; Classical Test Assumptions, Analysis Descriptive statistics, simple linear regression, Moderated Regression Analysis (MRA) and finally, testing the hypothesis that includes t-test and coefficient of determination. From the data analysis, result that contributions of compensation effect on job satisfaction of employees with positive direction and existence interaction between compensation contributions and leadership on job satisfaction. This means that leadership is a moderating variable between the contribution compensation on employee job satisfaction.
\end{abstract}

Keywords: Contributions Compensation, Job Satisfaction, Leadership. 


\section{PENDAHULUAN}

Karyawan adalah perencana, pelaku, dan selalu berperan aktif dalam setiap aktivitas perusahaan. Karyawan merupakan kekayaan utama suatu perusahaan, karena tanpa keikutsertaan mereka, aktivitas perusahaan tidak akan terjadi. Karyawan berperan aktif dalam menetapkan rencana, sistem proses, dan tujuan yang ingin dicapai (Hasibuan, 2013 : 12). Keberadaan karyawan disuatu perusahaan adalah tenaganya untuk perusahaan, selanjutnya perusahaan berkewajiban untuk memberikan kompensasi kepada karyawan yang telah menyumbangkan tenaga dan pikirannya. Besar kecilnya kompensasi yang diberikan kepada karyawan tergantung kepada besar kecilnya sumbangan tenaga dan pikiran yang diberikan kepada perusahaan (Tohardi, 2002 : 412).

Kompensasi adalah semua pendapatan yang berbentuk uang, barang langsung atau tidak langsung yang diterima karyawan sebagai imbalan atas jasa yang diberikan kepada perusahaan. Besarnya kompensasi mencerminkan status, pengakuan, dan tingkat pemenuhan kebutuhan yang dinikmati oleh karyawan bersama keluarganya. Jika balas jasa yang diterima karyawan semakin besar berarti jabatannya semakin tinggi, statusnya semakin baik, dan pemenuhan kebutuhan yang dinikmatinya semakin banyak pula. Dengan demikian, kepuasan kerjanya juga semakin baik (Hasibuan, 2013 : 118).

Kepuasan kerja karyawan adalah keadaan emosional karyawan dimana terjadi titik temu antara nilai balas jasa karyawan dari organisasi/perusahaan dengan nilai tingkat balas jasa yang memang diinginkan oleh karyawan yang bersangkutan. Bila kepuasan karyawan terjadi, maka pada umumnya tercermin pada perasaan karyawan terhadap pekerjaannya, yang sering diwujudkan dalam sikap positif karyawan terhadap pekerjaannya dan segala sesuatu yang dihadapi ataupun ditugaskan kepadanya di lingkungan kerjanya (Martoyo, 2007 : 142). Kepuasan kerja karyawan banyak dipengaruhi sikap pimpinan dalam kepemimpinannya. Kepemimpinan partisipasi memberikan kepuasan kerja bagi karyawan karena karyawan ikut aktif dalam memberikan pendapatnya untuk menentukan kebikjasanaan perusahaan. Kepemimpinan otoriter mengakibatkan kepuasan kerja karyawan rendah (Hasibuan, 2013 : 203).

Kepemimpinan adalah suatu proses kegiatan seseorang untuk menggerakkan orang lain dengan memimpin, membimbing, memengaruhi orang lain, untuk 
melakukan sesuatu agar dicapai hasil yang diharapkan. Dalam suatu organisasi, faktor kepemimpinan memegang peran-peran yang penting karena pemimpin itulah yang akan menggerakkan dan mengarahkan organisasi dalam mencapai tujuan dan sekaligus merupakan tugas yang tidak mudah, karena harus memahami setiap perilaku bawahan yang berbeda-beda. Bawahan dipengaruhi sedemikian rupa sehingga bisa memberikan pengabdian dan partisipasinya kepada organisasi secara efektif dan efisien. Dengan kata lain, bahwa sukses tidaknya usaha pencapaian tujuan organisasi ditentukan oleh kualitas kepemimpinan (Sutrisno, 2011 : 213).

Dalam meningkatkan kepuasan kerja karyawan UPT Bina Marga Jember dapat melalui pemberian kompensasi secara benar dan adil sebagaimana dikemukakan oleh Handoko (2012 : 57) kompensasi akan dapat meningkatkan ataupun menurunkan kepuasan kerja, oleh karena itu diperlukan perhatian organisasi terhadap pengaturan kompensasi secara benar dan adil, apabila para karyawan memandang kompensasi mereka tidak memadai, maka prestasi kerja maupun kepuasan kerja mereka akan menurun. Serta dengan kepemimpinan yang baik karena kepuasan dapat ditingkatkan melalui perhatian dan hubungan yang baik dari pimpinan kepada bawahan, sehingga karyawan akan merasa bahwa dirinya merupakan bagian yang penting dari organisasi kerja (Sutrisno, 2011 : 79).

Ketidakpuasan dalam kerja akan dapat menimbulkan perilaku agresif, atau sebaliknya akan menunjukkan sikap menarik diri dari kontak dengan lingkungan sosialnya. Misalnya, dengan mengambil sikap berhenti dari perusahaan, suka bolos, dan perilaku lain yang cenderung bersifat menghindari dari aktivitas organisasi (Sutrisno, 2011 : 82). Absensi dalam perusahaan merupakan masalah karena absensi berarti kerugian akibat terhambatnya penyelesaian pekerjaan, hal ini juga merupakan indikasi adanya ketidakpuasan kerja karyawan yang dapat merugikan perusahaan (Robbins, 2006). Dalam pra penelitian yang telah dilakukan, peneliti memperoleh data absensi dan turn over karyawan UPT Bina Marga Jember dalam periode 1 tahun dari bulan April 2013 s/d Maret 2014. 
Tabel 1. Daftar Ketidakhadiran Karyawan Bulan April 2013 s/d Maret 2014

\begin{tabular}{|l|c|c|c|c|}
\hline \multicolumn{1}{|c|}{ Bulan } & $\begin{array}{c}\text { Jumlah } \\
\text { Karyawan }\end{array}$ & $\begin{array}{c}\text { Rata-rata Hari } \\
\text { Kerja }\end{array}$ & $\begin{array}{c}\text { Jumlah Ketidak } \\
\text { hadiran } \\
\text { Karyawan }\end{array}$ & Persentase (\%) \\
\hline April & 35 & 24 & 16 & $1,90 \%$ \\
\hline Mei & 34 & 24 & 8 & $0,98 \%$ \\
\hline Juni & 33 & 24 & 13 & $1,64 \%$ \\
\hline Juli & 33 & 24 & 7 & $0,88 \%$ \\
\hline Agustus & 33 & 24 & 9 & $1,13 \%$ \\
\hline September & 33 & 24 & 11 & $1,38 \%$ \\
\hline Oktober & 34 & 24 & 11 & $1,34 \%$ \\
\hline November & 34 & 24 & 6 & $0,73 \%$ \\
\hline Desember & 32 & 24 & 11 & $1,43 \%$ \\
\hline Januari & 33 & 24 & 13 & $1,64 \%$ \\
\hline Februari & 30 & 20 & 19 & $3,16 \%$ \\
\hline Maret & 31 & 20 & 15 & $2,41 \%$ \\
\hline
\end{tabular}

Sumber: UPT Bina Marga Jember, Data diolah.

Dilihat dari tabel 1. menunjukkan bahwa tingkat absensi karyawan dalam periode 1 tahun dari bulan April 2013 s/d Maret 2014 relatif tidak stabil dan cenderung mengalami peningkatan. Tingkat absensi karyawan yang paling tinggi terjadi pada bulan Februari tahun 2014 mencapai 3,16\%.

Tabel 2. Daftar Turn Over karyawan bulan April 2013 s/d Maret 2014

\begin{tabular}{|l|c|c|c|c|}
\hline \multicolumn{1}{|c|}{ Bulan } & $\begin{array}{c}\text { Jumlah } \\
\text { Karyawan } \\
\text { Masuk }\end{array}$ & $\begin{array}{c}\text { Jumlah } \\
\text { Karyawan } \\
\text { Keluar }\end{array}$ & $\begin{array}{c}\text { Jumlah } \\
\text { Karyawan }\end{array}$ & Persentase (\%) \\
\hline April & 0 & 0 & 35 & \\
\hline Mei & 0 & 1 & 34 & \\
\hline Juni & 0 & 1 & 33 & \\
\hline Juli & 0 & 0 & 33 & \\
\hline Agustus & 0 & 0 & 33 & \\
\hline September & 0 & 0 & 33 & \\
\hline Oktober & 2 & 1 & 34 & \\
\hline November & 0 & 0 & 34 & \\
\hline Desember & 0 & 2 & 32 & \\
\hline Januari & 1 & 0 & 33 & \\
\hline Februari & 0 & 3 & 30 & \\
\hline Maret & 1 & 0 & 31 & \\
\hline Jumlah & 4 & 8 & & $24,24 \%$ \\
\hline Sumber: UPT Binaly
\end{tabular}

Sumber: UPT Bina Marga Jember, Data diolah. 
Dilihat dari tabel 2. menunjukkan bahwa tingkat turn over karyawan dalam periode 1 tahun dari bulan April 2013 s/d Maret 2014 mencapai 24,24\%. Dalam periode 1 tahun jumlah karyawan yang keluar lebih banyak dari jumlah karyawan yang masuk yaitu sebanyak 4 orang karyawan yang masuk sedangkan jumlah karyawan yang keluar sebanyak 8 orang karyawan.

Ketidakhadiran dan berhenti bekerja merupakan jenis jawaban-jawaban secara kualitatif berbeda. Ketidakhadiran lebih spontan sifatnya dan dengan demikian kurang mencerminkan ketidakpuasan kerja. Lain halnya dengan berhenti atau keluar dari pekerjaan. Perilaku ini karena akan mempunyai akibat-akibat ekonomis yang besar, maka lebih besar kemungkinannya ia berhubungan dengan ketidakpuasan kerja (Sutrisno, $2011: 81$ ).

\section{Perumusan Masalah}

1. Apakah kontribusi kompensasi memengaruhi kepuasan kerja karyawan UPT. Bina Marga Jember?

2. Apakah ada interaksi antara kontribusi kompensasi dan kepemimpinan terhadap kepuasan kerja karyawan UPT. Bina Marga Jember?

Kerangka konseptual dan hipotesis dalam penelitian ini adalah sebagai berikut:

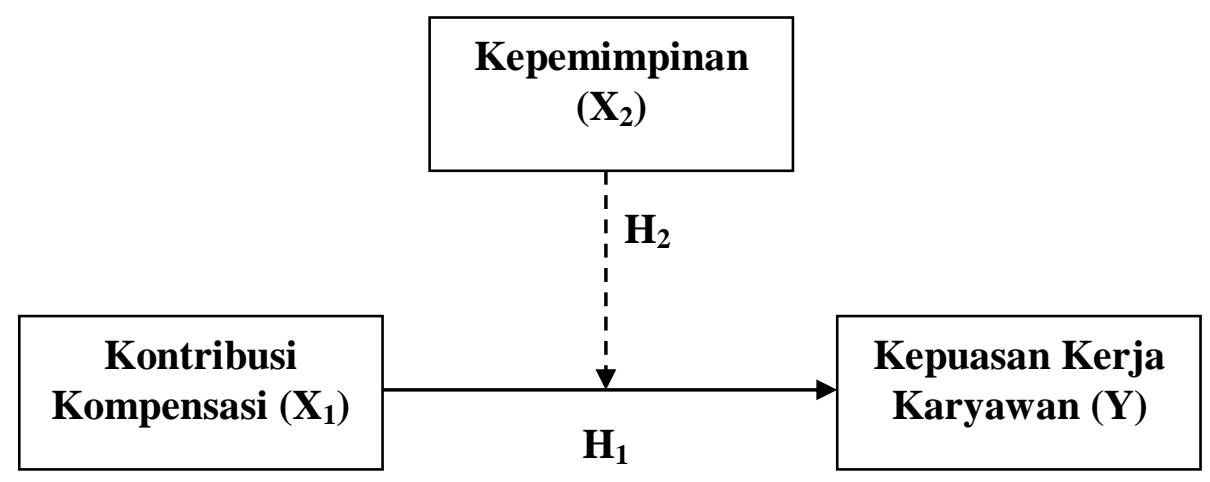

Gambar 2.1. Kerangka Konseptual Penelitian.

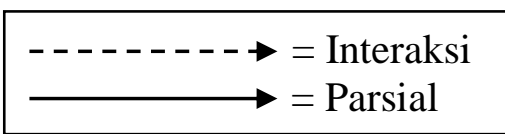

Hipotesis adalah suatu pernyataan yang masih harus diuji kebenarannya secara empiris (Iskandar, 2008 : 56). Hipotesis dalam penelitian ini adalah sebagai berikut:

1. $\mathbf{H}_{1}$ : Kontribusi kompensasi memengaruhi kepuasan kerja karyawan UPT Bina Marga Jember. 
2. $\mathbf{H}_{2}$ : Ada interaksi antara kontribusi kompensasi dan kepemimpinan terhadap kepuasan kerja karyawan UPT Bina Marga Jember.

\section{METODE PENELITIAN}

Berdasarkan rumusan masalah, tujuan penelitian dan kerangka konseptual dalam penelitian, karakteristik masalah yang diteliti dalam penelitian ini dapat diklasifikasikan sebagai explanatory research yaitu penelitian yang menjelaskan hubungan dan menguji keterkaitan antara beberapa variabel melalui pengujian hipotesis atau penelitian penjelasan, (Singarimbun, $2006: 256$ ).

Sugiyono (2012 : 115) menyatakan bahwa populasi adalah wilayah generalisasi yang terdiri atas objek/subjek yang mempunyai kualitas dan karakteristik tertentu yang ditetapkan oleh peneliti untuk dipelajari dan kemudian ditarik kesimpulannya. Populasi dalam penelitian ini adalah seluruh karyawan UPT Bina Marga Jember yang meliputi kantor kas di Rambipuji, Kalisat dan Sukowono. yaitu sebanyak 31 orang karyawan dan akan dilibatkan sebagai responden.

Definisi operasional variabel dalam penelitian ini dijelaskan sebagai berikut:

\section{Kontribusi Kompensasi $\left(\mathrm{X}_{1}\right)$}

Segala sesuatu yang diterima oleh karyawan sebagai balas jasa untuk kerja mereka (Handoko, 2012).

a. Dimensi: Kompensasi Finansial dan Non Finansial.

b. Indikator: Gaji, Insentif, Bonus, Tunjangan, Fasilitas, Pujian dan Pengakuan.

2. Kepuasan Kerja Karyawan (Y)

Keadaan emosional yang menyenangkan atau tidak menyenangkan bagi para karyawan memandang pekerjaan mereka (Handoko, 2012).

a. Dimensi (Luthans, 2011):

Kepuasan kerja adalah respon emosional terhadap situasi kerja, Kepuasan kerja diartikan sebagai seberapa baik hasil yang diperoleh memenuhi harapan, Kepuasan kerja menyajikan perhatian atau attitude yang berkaitan dengan pekerjaan.

b. Indikator (Robbins, 2002):

Kondisi kerja yang mendukung, Rekan kerja yang mendukung, Ganjaran yang pantas, Kerja yang secara mental menantang, Kesesuaian kepribadian dengan pekerjaan. 
3. Kepemimpinan $\left(\mathrm{X}_{2}\right)$

Cara seorang pemimpin memengaruhi perilaku bawahan, agar mau bekerja sama dan bekerja secara produktif untuk mencapai tujuan organisasi. (Hasibuan, 2013).

a. Dimensi (Martoyo, 2007 : 176):

Kemampuan analitis, Ketrampilan berkomunikasi, Keberanian, Kemampuan mendengar, Ketegasan.

b. Indikator:

Kemampuan menganalisa situasi yang dihadapi, Dalam memberikan perintah, petunjuk, pedoman, nasehat, Keberanian dalam melaksanakan tugas pokok yang telah dipercayakan, Kemampuan serta kemauan mendengar pendapat dan atau saran-saran, Ketegasan dalam menghadapi bawahan dan ketidaktentutan.

\section{HASIL DAN PEMBAHASAN}

\section{Hasil Analisis Regresi Linear Sederhana Dan Moderated Regression Analysis (MRA)}

Analisis efek moderasi berkaitan interaksi antara variabel independen (prediktor) dengan variabel moderator dalam memengaruhi variabel dependen. Pertama adalah menguji efek utama dengan menggunakan regresi linear sederhana. Kedua adalah menguji efek moderasi dengan menggunakan moderated regression analysis (MRA). Hasil analisis efek utama antara variabel independen yaitu kontribusi kompensasi dan variabel dependen yaitu kepuasan kerja karyawan. Hasil analisis efek moderasi antara variabel independen yaitu kontribusi kompensasi, variabel moderator yaitu kepemimpinan, serta variabel dependen yaitu kepuasan kerja karyawan.

Tabel 3. Hasil Analisis Efek Utama.

\begin{tabular}{|l|c|c|c|c|c|c|c|c|}
\hline \multicolumn{1}{|c|}{ Variabel } & $\begin{array}{c}\text { Unstandardiz } \\
\text { ed }\end{array}$ & $\mathrm{t}$ & & $\mathrm{t}_{\text {tabel }}$ & Sig. & & $a$ & Keterangan \\
\cline { 2 - 3 } & Coefficients B & & & & & & \\
\hline Constant & 1,412 & & & & & & & \\
\hline $\begin{array}{l}\text { Kontribusi } \\
\begin{array}{l}\text { Kompensasi } \\
\left(\mathrm{X}_{1}\right)\end{array}\end{array}$ & 0,653 & 7,107 & $>$ & 2,045 & 0,000 & $<$ & 0,05 & Signifikan \\
\hline$R$ Square $=0,653$ & & & & & & \\
\hline
\end{tabular}

Sumber: Data Diolah

Berdasarkan koefisien regresi, maka persamaan regresi yang dapat dibentuk adalah: 


$$
\mathrm{Y}=1,412+0,653 \mathrm{X}_{1}
$$

1. Nilai konstanta 1,412, menunjukkan bahwa jika tidak ada aktivitas pada kontribusi kompensasi maka nilai kepuasan kerja karyawan sebesar 1,412.

2. Nilai koefisien 0,653 pada kontribusi kompensasi, menunjukkan bahwa setiap kenaikan kegiatan kontribusi kompensasi 1 satuan, maka hal tersebut akan meningkatkan kepuasan kerja karyawan sebesar 0,653 dan sebaliknya.

Tabel 4.13. Hasil Analisis Efek Moderasi.

\begin{tabular}{|l|c|c|c|c|c|c|c|c|}
\hline \multicolumn{1}{|c|}{ Variabel } & $\begin{array}{c}\text { Unstandardiz } \\
\text { ed }\end{array}$ & $\mathrm{t}$ & & $\mathrm{t}_{\text {tabel }}$ & Sig. & & $a$ & Keterangan \\
\cline { 2 - 8 } & $\begin{array}{c}\text { Coefficients } \\
B\end{array}$ & & & & & & \\
\hline Constant & 0,630 & & & & & & & \\
\hline $\begin{array}{l}\text { Kontribusi } \\
\begin{array}{l}\text { Kompensasi } \\
\left(\mathrm{X}_{1}\right)\end{array}\end{array}$ & 0,279 & 3,231 & $>$ & 2,051 & 0,003 & $<$ & 0,05 & Signifikan \\
\hline $\begin{array}{l}\text { Kepemimpinan } \\
\left(\mathrm{X}_{2}\right)\end{array}$ & 0,558 & 5,833 & $>$ & 2,051 & 0,000 & $<$ & 0,05 & Signifikan \\
\hline $\begin{array}{l}\text { Interaksi } \\
\left(\mathrm{X}_{1} \mathrm{X}_{2}\right)\end{array}$ & 0,303 & 3,426 & $>$ & 2,051 & 0,002 & $<$ & 0,05 & Signifikan \\
\hline \begin{tabular}{l} 
Adjusted R Square $=0,822$ \\
\hline
\end{tabular}
\end{tabular}

Sumber: Data Diolah.

Berdasarkan koefisien regresi, maka persamaan regresi yang dapat dibentuk adalah:

$$
\mathrm{Y}=0,630+0,279 \mathrm{X}_{1}+0,558 \mathrm{X}_{2}+0,303 \mathrm{X}_{1} \mathrm{X}_{2}
$$

1. Nilai konstanta 0,630 menunjukkan bahwa jika tidak ada aktivitas pada kontribusi kompensasi, kepemimpinan dan interaksi 1 maka nilai kepuasan kerja karyawan sebesar 0,630.

2. Nilai koefisien 0,279 pada kontribusi kompensasi, menunjukkan bahwa setiap kenaikan kegiatan kontribusi kompensasi 1 satuan, maka hal tersebut akan meningkatkan kepuasan kerja karyawan sebesar 0,279 dan sebaliknya.

3. Nilai koefisien 0,558 pada kepemimpinan, menunjukkan bahwa setiap kenaikan kegiatan kepemimpinan 1 satuan, maka hal tersebut akan meningkatkan kepuasan kerja karyawan sebesar 0,558 dan sebaliknya.

4. Nilai koefisien 0,303 pada interaksi 1, menunjukkan bahwa setiap kenaikan kegiatan interaksi 11 satuan, maka hal tersebut akan meningkatkan kepuasan kerja karyawan sebesar 0,303 dan sebaliknya. 


\section{Hasil Uji t}

\section{Hasil Uji t Analisis Efek Utama}

Pengujian ini dilakukan untuk mengetahui apakah variabel independen berpengaruh terhadap variabel dependen secara signifikan secara parsial. Tabel distribusi $\mathrm{t}$ dicari pada $\alpha=5 \%$, dengan derajat kebebasan (df) n-k-1 atau 31-1-1 =29. Hasil analisis regresi sederhana adalah untuk mengetahui pengaruh kontribusi kompensasi terhadap variabel dependen yaitu kepuasan kerja karyawan.

Berdasarkan hasil analisis regresi sederhana diperoleh hasil yang dapat dinyatakan yaitu variabel kontribusi kompensasi $\left(\mathrm{X}_{1}\right)$ memiliki nilai t 7,107 > 2,045 dan signifikansi $0,000<0,05$, maka Ho ditolak dan Ha diterima, yang berarti secara parsial variabel kontribusi kompensasi berpengaruh signifikan terhadap kepuasan kerja karyawan UPT Bina Marga Jember. $t_{\text {hitung }}$ positif, maka jika ada peningkatan pada variabel kontribusi kompensasi maka akan meningkatkan kepuasan kerja karyawan.

\section{Hasil Uji t Analisis Efek Moderasi}

Pengujian ini dilakukan untuk mengetahui apakah variabel independen dan moderator berpengaruh terhadap variabel dependen secara signifikan secara parsial. Tabel distribusi t dicari pada $\alpha=5 \%$, dengan derajat kebebasan (df) n-k-1 atau 31-3-1 = 27. Hasil analisis moderated regression analysis (MRA) adalah untuk mengetahui pengaruh kontribusi kompensasi, kepemimpinan serta interaksi 1 terhadap variabel dependen yaitu kepuasan kerja karyawan.

Berdasarkan hasil analisis moderated regression analysis (MRA) (dalam hal ini untuk menguji pengaruh secara parsial) diperoleh hasil yang dapat dinyatakan berikut:

a. Variabel kontribusi kompensasi $\left(\mathrm{X}_{1}\right)$ memiliki nilai t 3,231>2,051 dan signifikan 0,003 < 0,05, maka Ho ditolak dan Ha diterima, yang berarti secara parsial variabel kontribusi kompensasi berpengaruh signifikan terhadap kepuasan kerja karyawan UPT Bina Marga Jember. $t_{\text {hitung }}$ positif, maka jika ada peningkatan pada variabel kontribusi kompensasi maka akan meningkatkan kepuasan kerja karyawan.

b. Variabel kepemimpinan $\left(\mathrm{X}_{2}\right)$ memiliki nilai t 5,833>2,051 dan signifikansi $0,000<0,05$, maka Ho ditolak dan Ha diterima, yang berarti secara parsial variabel kepemimpinan berpengaruh signifikan terhadap kepuasan kerja karyawan UPT Bina Marga Jember. $t_{\text {hitung }}$ positif, maka jika ada peningkatan pada variabel kepemimpinan maka akan meningkatkan kepuasan kerja karyawan. 
c. Variabel interaksi $1\left(\mathrm{X}_{1} \mathrm{X}_{2}\right)$ memiliki nilai t 3,426>2,051 dan signifikan 0,002< 0,05, maka Ho ditolak dan Ha diterima, yang berarti ada interaksi antara kontribusi kompensasi dan kepemimpinan terhadap kepuasan kerja karyawan UPT. Bina Marga Jember. Hal ini berarti bahwa kepemimpinan merupakan variabel pemoderasi.

\section{Pembahasan}

Hasil pengujian koefisien dari analisis efek utama, menunjukkan bahwa kontribusi kompensasi berpengaruh signifikan terhadap kepuasan kerja karyawan UPT Bina Marga Jember dengan arah positif. Hasil pengujian koefisien dari analisis efek moderasi, menunjukkan bahwa interaksi antara kontribusi kompensasi dan kepemimpinan sebagai variabel pemoderasi terhadap kepuasan kerja karyawan UPT Bina Marga Jember.

Berdasarkan hasil pengujian tersebut, maka dapat disimpulkan bahwa hipotesis yang menyatakan, "ada pengaruh kontribusi kompensasi terhadap kepuasan kerja karyawan UPT Bina Marga Jember" dan "ada interaksi antara kontribusi kompensasi dan kepemimpinan sebagai variabel pemoderasi terhadap kepuasan kerja karyawan UPT Bina Marga Jember" adalah diterima.

\section{Pengaruh Kontribusi Kompensasi Terhadap Kepuasan Kerja Karyawan}

Penelitian yang dilakukan, menunjukkan bahwa nilai koefisien variabel kontribusi kompensasi sebesar 0,635 atau 63,5\% dengan arah positif. Handoko (2012 : 155) menyatakan bahwa Kompensasi adalah segala sesuatu yang diterima para karyawan sebagai balas jasa untuk kerja mereka. Bila kompensasi diberikan secara benar, para karyawan akan lebih terpuaskan dan termotivasi untuk mencapai sasaransasaran organisasi. Kompensasi akan dapat meningkatkan ataupun menurunkan kepuasan kerja, oleh karena itu diperlukan perhatian organisasi terhadap perngaturan kompensasi secara benar dan adil, apabila para karyawan memandang kompensasi mereka tidak memadai, maka prestasi kerja maupun kepuasan kerja mereka akan menurun.

Kepuasan kerja (Job Satisfaction) adalah keadaan emosional yang menyenangkan atau tidak menyenangkan dengan mana para karyawan memandang pekerjaan mereka. Kepuasan kerja mencerminkan perasaan seseorang terhadap 
pekerjaannya. Ini nampak dari sikap karyawan terhadap pekerjaan dan segala sesuatu di lingkungan kerjanya (Handoko, 2012 : 193).

\section{Pengaruh Kepemimpinan Sebagai Moderating Variable Antara Kontribusi Kompensasi Terhadap Kepuasan Kerja Karyawan}

Penelitian yang dilakukan, menunjukkan bahwa nilai koefisien variabel interaksi 1 antara kontribusi kompensasi dengan kepemimpinan sebagai moderating variable terhadap kepuasan kerja sebesar 0,303 atau 30,3\% dengan arah positif. Hasibuan (2013 : 203) menyatakan bahwa kepuasan kerja karyawan banyak dipengaruhi sikap pimpinan dalam kepemimpinannya. Perusahaan merupakan organisasi bisnis yang terdiri atas orang-orang, maka pimpinan seharusnya dapat menyelaraskan antara kebutuhan-kebutuhan individu dengan kebutuhan organisasi yang dilandasi oleh hubungan manusiawi. Sejalan dengan itu diharapkan seorang pimpinan mampu memotivasi dan menciptakan kondisi sosial yang menguntungkan setiap karyawan sehingga tercapainya kepuasan kerja karyawan yang berimplikasi pada meningkatnya produktivitas kerja karyawan (Robbins, 2002 : 181).

Dengan pemberian kompensasi terjalinlah ikatan kerja sama formal antara majikan dengan karyawan. Karyawan harus mengerjakan tugas-tugasnya dengan baik. Dengan balas jasa, karyawan akan dapat memenuhi kebutuhan-kebutuhan fisik, status sosial, dan egoistiknya sehingga memperoleh kepuasan kerja dari jabatannya (Hasibuan, 2013 : 121). Pada hakikatnya, kepuasan kerja merupakan perasaan senang atau senang pekerja dalam memandang dan menjalankan pekerjaannya. Apabila seseorang senang terhadap pekerjaannya, maka orang tersebut puas terhadap pekerjaannya (Sutrisno $2011: 75$ ).

\section{KESIMPULAN DAN SARAN}

Berdasarkan hasil analisis yang telah dilakukan pada penelitian ini, maka dapat ditarik kesimpulan sebagai berikut:

1. Kontribusi kompensasi berpengaruh terhadap kepuasan kerja karyawan UPT Bina Marga Jember dengan arah positif. Hal ini mendukung adanya temuan bahwa dengan adanya pemberian kompensasi yang sesuai maka akan meningkatkan kepuasan kerja.

2. Ada interaksi antara kontribusi kompensasi dan kepemimpinan terhadap kepuasan kerja karyawan UPT Bina Marga Jember. Hal ini berarti bahwa 
kepemimpinan merupakan variabel pemoderasi antara kontribusi kompensasi terhadap kepuasan kerja karyawan.

\section{Keterbatasan Penelitian}

Keterbatasan penelitian ini antara lain :

1. Penelitian ini hanya meneliti kaitan kompensasi saja terhadap kepuasan karyawan dengan kepemimpinan sebagai moderating variabel. Padahal masih banyak variabel yang bisa mempengaruhi kepuasan kerja, seperti motivasi, pendidikan dan pelatihan, serta suasana kerja yang kondusif.

2. Penelitian melibatkan subjek penelitian dalam jumlah terbatas, yakni sebanyak 31 karyawan , sehingga hasilnya belum dapat digeneralisasikan pada kelompok subjek dengan jumlah yang besar.

\section{Saran}

Berdasarkan hasil penelitian dan kesimpulan, maka dapat disarankan sebagai berikut:

1. Pihak Manajemen UPT Bina Marga Jember diharapkan dapat lebih menyesuaikan dan mengembangkan kompensasi yang diberikan, diharapkan karyawan akan merasa lebih sesuai dan puas dengan tugas atau beban kerja yang telah ditanggung jawabkan kepadanya.

2. Pihak Manajemen UPT Bina Marga Jember diharapkan dapat lebih mengembangkan sifat kepemimpinan yang transformatif, diharapkan karyawan yang berkerja dapat berkerja lebih optimal dan tepat sehingga karyawan dapat menampilkan hasil kerja yang baik yang akan menjadikan record dan prestasi untuk penilaian pemberian kompensasi yang sesuai sehingga kepuasan kerja akan meningkat.

\section{DAFTAR PUSTAKA}

Arikunto, Suharsimi. 2006. Prosedur Penelitian, Suatu Pendekatan Praktek. Jakarta: Rineka Cipta.

Ghozali, Imam. 2005. Aplikasi Analisis Multivariate dengan Program SPSS. Edisi Ketiga. Semarang: BP Universitas Diponegoro.

Handoko, T. Hani. 2012, Manajemen Personalia Dan Sumber Daya Manusia. Edisi Kedua. Cetakan ke-19. Yogyakarta: BPFE. 
Hasibuan, Malayu S.P. 2013. Manajemen Sumber Daya Manusia. Edisi Revisi. Cetakan ke-17. Jakarta: PT. Bumi Aksara.

Iskandar. 2008. Metodologi Penelitian Pendidikan dan Sosial (Kuantitatif dan Kualitatif). Jakarta: Gaung Persada Press.

Latan, Hengky. 2013. Analisis Multivariat Teknik dan Aplikasi. Bandung: Alfabeta.

Luthans, Fred. 2011. Organizational Behaviour An Evidence Based approach. New York: Mc.Graw-Hill International Book Company.

Martoyo, Susilo. 2007. Manajemen Sumber Daya Manusia. Edisi Kelima Cetakan ke-1. Yogyakarta: BPFE.

Prayitno, Duwi. 2010. Paham Analisa Data Statistik Dengan SPSS. Yogyakarta: MediaKom.

Robbins, Stephen. P. 2002. Perilaku Organisasi, Konsep, Kontroversi dan Aplikasi. Edisi Kedelapan. Jilid 2. Jakarta: PT. Prenhallindo.

. 2006. Teori Organisasi: Struktur, Desain Dan Aplikasi. Alih Bahasa: Yusuf Udaya. Jakarta: Arcan.

Singarimbun, M dan Effendi, S. 2006. Metode Penelitian Survei. Cetakan ke-18. Jakarta: Penerbit Pustaka LP3ES.

Sugiyono. 2012. Metode Penelitian Kuantitatif Kualitatif dan RD. Bandung: Alfabeta.

Sutrisno, Edy. 2011. Manajemen Sumber Daya Manusia. Edisi Pertama. Cetakan ke-3. Jakarta: Kencana Prenada Media Group.

Tohardi, Ahmad. 2002. Pemahaman Manajemen Sumber Daya Manusia. Bandung: Mandar Maju. 